\title{
Cellular hypersensitivity to a synthetic dodecapeptide derived from human adenovirus 12 which resembles a sequence of A-gliadin in patients with coeliac disease
}

\author{
G J Mantzaris, J A Karagiannis, J D Priddle, D P Jewell
}

\begin{abstract}
The human intestinal adenovirus serotype 12 (Ad12) may be implicated in the pathogenesis of coeliac disease by virtue of immunological cross reactivity between epitopes shared by its early region Elb protein and A-gliadin. In the present study a synthetic dodecapeptide from the corresponding viral epitope (Ad12E1b, residues 384-395) was tested for its effect on peripheral blood mononuclear cells from 22 treated and eight untreated patients with coeliac disease, 22 healthy subjects, 11 patients with ulcerative colitis, and 11 patients with Crohn's disease by an indirect leucocyte migration inhibition assay. In addition, the effect of both the viral and the gliadin synthetic peptides was studied by proliferation and migration assays simultaneously performed in an unselected subgroup of 12 treated coeliac patients and 12 healthy subjects of the study. Coeliac patients with untreated disease showed no response to the viral peptide compared with treated patients $(p>0 \cdot 1)$. Treated coeliac patients showed a significantly different response from healthy control subjects and control patients with disease $(\mathbf{p}<0.001)$ which was dependent on the concentration of the viral peptide. In the subgroup of the treated coeliac patients $(n=12)$ there was a significant correlation between the responses in the migration and the proliferation assay using either the viral $(p<0.02)$ or the gliadin $(p<0.005)$ peptide at the highest concentration $(33.3 \mu \mathrm{g} / \mathrm{ml})$. Furthermore, the responses obtained using viral peptide correlated significantly with the responses obtained with gliadin peptide in both the migration $(p<0.001)$ and the proliferation $(p<0.001)$ assays. These results show that in coeliac patients there is pronounced cross reactivity at the level of $T$ cell recognition between synthetic peptides derived from the Ad12 and A-gliadin. This antigenic cross reactivity may be involved in the pathogenesis of coeliac disease.
\end{abstract}

Gastroenterology Unit, Radcliffe Infirmary, Oxford OX2 6HE

G J Mantzaris

J A Karagiannis

J D Priddle

D P Jewell

Correspondence to: Dr D P Jewell.

Accepted for publication 4 September 1989
Coeliac disease is due to an adverse reaction to dietary gluten which results in damage to the small intestinal mucosa and subsequent malabsorption. However, gluten is a complex mixture of many proteins which broadly fall into two groups: gliadins and glutenins. Four fractions of gliadins can be obtained by electrophoresis ${ }^{1}: \alpha$ and $\beta$ gliadins are toxic for coeliac patients, whereas there is disagreement concerning the toxicity of $\gamma$ and $\omega$ gliadins. ${ }^{2} \mathrm{~A}$-gliadin is a major component of $\alpha$ gliadins and is known to be toxic. ${ }^{34}$ Its primary structure has recently been determined. ${ }^{5}$

Genetic factors are important in determining susceptibility to coeliac disease. ${ }^{6-10}$ However, the well documented discordance for disease in monozygotic twins and HLA identical siblings $^{81112}$ as well as the failure of additional gluten intake to induce small intestinal damage in these groups ${ }^{13}$ offer the best argument that environmental factors in addition to gluten may also play a part in the pathogenesis of this disease. Kagnoff $e t$ al have reported a region of sequence homology between A-gliadin (residues 205-217) and the Elb protein (residues 384-395) of human intestinal adenovirus 12 (Ad12). ${ }^{14}$ Within 12 amino acids they share eight identities. ${ }^{314}$ Both structures are hydrophilic and so are likely to be located on the exterior of the molecule. ${ }^{\text {is }}$ Kagnoff et al postulated that, because of this shared epitope, an immune response to Ad12 might render genetically susceptible individuals to become sensitised to gluten in such a way as to lead to coeliac disease. ${ }^{\text {It }}$ They found that antibodies raised to Elb protein cross react with A-gliadin, ${ }^{16}$ a 119 cyanogen bromide fragment of A-gliadin containing the 206-217 sequence, ${ }^{16}$ and a synthetic A-gliadin heptapeptide from within the region of sequence homology. ${ }^{14}$ Specific A-gliadin peptides, including the 119 cyanogen bromide fragment, show toxicity in organ tissue culture assays of jejunal biopsy specimens obtained from untreated patients with coeliac disease. ${ }^{17}$ Serological evidence of past exposure to $\mathrm{Adl} 12$ is more common in coeliac patients than in healthy subjects, ${ }^{18}$ although increased titres of antibody specific to the dodecapeptide (residues 206-217) have not been found in coeliac patients. ${ }^{19}$ However, cell mediated immunity to a synthetic peptide comprising A-gliadin residues 206-217 has been shown in treated coeliac patients using indirect leucocyte migration inhibition assays and proliferation assays. ${ }^{2021}$ The aim of our study was to investigate cellular immune responses to a synthetic peptide from the corresponding viral epitope (Ad12E1b residues 384-395) in coeliac patients and control subjects and to compare the results with those obtained concurrently using the synthetic dodecapeptide from gliadin.

\section{Methods}

PATIENTS

Twenty two treated patients (nine men, 13 
women, age range $20-68$ years) and eight untreated patients (two men, six women, age range 35-54 years) with coeliac disease were studied. Five of the untreated patients were studied both at the time of diagnosis and three to five months after they had been on a gluten free diet. The other 17 treated coeliac patients had been on a gluten free diet from between one and 15 years. Initially, all patients had subtotal villous atrophy consistent with coeliac disease, but showed a satisfactory clinical and histological response to gluten withdrawal and were being maintained on a strict gluten free diet at the time of testing.

The control group consisted of 22 healthy subjects (nine men, 13 women, age range 20-68 years) and 22 patients with inflammatory bowel disease. Eleven of those patients had Crohn's disease (five men, six women, age range 34-80 years) and 11 had ulcerative colitis (four men, seven women, age range $20-80$ years). All disease control patients were in remission and had not been treated with steroids in the two months before entering the study or other immunosuppressive treatment in the six months before the study.

\section{HLA TYPING}

All coeliac patients and healthy subjects were tested serologically for HLA-A, B, C, DR, ${ }^{22}$ and DQ loci.

\section{PEPTIDES}

The viral (Ad12E1b 384-395) and the gliadin (Agliadin 206-217) sequences were synthesised by solid phase methods. The structure of the peptides was as follows:

Ad12E1b: Leu-Arg-Arg-Gly-Met-Phe-Arg-Pro-Ser-Gln-Cys-Asn A-gliadin: Leu-Gly-Gln-Gly-Ser-Phe-Arg-Pro-Ser-Gln-Gln-Asn

Both peptides were homogeneous and ran as a single peak on high performance liquid chromatography. They were diluted in phosphate buffered saline $(\mathrm{pH} 7 \cdot 3)$ and after filter sterilisation $(0.22 \mu \mathrm{m})$ samples were stored at $-20^{\circ} \mathrm{C}$.

\section{INDIRECT LEUCOCYTE MIGRATION}

INHIBITION ASSAYS

Indirect leucocyte migration inhibition assays were performed according to the method of Clausen, ${ }^{23}$ as described previously..$^{20}$ Briefly, peripheral blood mononuclear cells from coeliac patients and control subjects were incubated in the presence (stimulated cultures) and the absence (control cultures) of the viral synthetic peptide at concentrations of $33 \cdot 3,11 \cdot 1$, and $5 \cdot 55$ $\mu \mathrm{g} / \mathrm{ml}$ for 72 hours at $37^{\circ} \mathrm{C}$ in a $5 \%$ carbon dioxide humidified atmosphere. The release of migration inhibition factor was assayed by its effect on the migration under agarose of polymorphonuclear cells from healthy donors. Results are expressed as a migration index (MI) which is calculated as follows:

\footnotetext{
mean migration area of cells incubated with stimulated culture supernatants

Using the gliadin synthetic peptide at $33 \cdot 3 \mu \mathrm{g} /$ $\mathrm{ml}$, additional migration inhibition assays were performed in an unselected subgroup of 12 of the 22 treated coeliac patients and 12 of the 22 healthy subjects matched for age and sex.

\section{PROLIFERATION ASSAYS}

Proliferation assays were performed simultaneously with the migration assays in the subgroup of 12 treated coeliac patients and healthy subjects. Briefly, peripheral blood mononuclear cells from treated coeliac patients and healthy subjects were suspended in RPMI 1640 containing $25 \mathrm{mmol}$ Hepes, $300 \mathrm{mg} / \mathrm{l} \mathrm{L}$-glutamine, $10 \%$ heat inactivated fetal calf serum, and antibiotics. Triplicate cultures in $96 \mathrm{U}$ shape bottomed microtitre plates (Sterilin, Feltham, UK) contained $1 \times 10^{6}$ viable cells with or without the viral or the gliadin peptide (at $33 \cdot 3,11 \cdot 1$, and 5.55 $\mu \mathrm{g} / \mathrm{ml}$ ) in a final volume of $200 \mu \mathrm{l}$. Phytohaemagglutinin (Wellcome, Kent) $10 \mu \mathrm{g} / \mathrm{ml}$ was used as mitogen in control cultures (without peptide) $(10 \mu \mathrm{g} / \mathrm{ml}$ gave maximal stimulation in the range $0.5-20 \mu \mathrm{g} / \mathrm{ml}$ as determined in preliminary experiments). Cells were incubated for six days at $37^{\circ} \mathrm{C}$ in a $5 \%$ carbon dioxide humidified atmosphere (six days' incubation was optimal as determined by preliminary experiments). Sixteen hours before the end of the incubation period individual cultures were pulsed with $1 \mu \mathrm{Ci}$ [methyl- ${ }^{3} \mathrm{H}$ ]-thymidine (Amersham Radiochemicals, Amersham, Bucks) and then subsequently harvested onto glass-fibre scintillation discs (Flow Lab, Irvine). The incorporation of [methyl- ${ }^{3} \mathrm{H}$ ]-thymidine was determined in a $\beta$-scintillation counter (LKB Rackbeta, Sweden). Results are expressed as a stimulation index (SI), which is calculated as follows:

$$
\mathrm{SI}=\frac{\begin{array}{c}
\text { mean (of three) dpm in cultures with peptide or } \\
\text { phytohaemagglutinin - mean (of three) dpm in } \\
\text { cell free cultures (culture medium alone) }
\end{array}}{\begin{array}{c}
\text { mean (of three) dpm in cultures without peptide } \\
\text { or phytohaemagglutinin - mean (of three) dpm in } \\
\text { cell free cultures (culture medium) }
\end{array}}
$$

The viability of the cells was more than $99 \%$ at the beginning and more than $87 \%$ at the end of the incubation period as determined by trypan blue exclusion.

\section{STATISTICAL ANALYSIS}

As the observations in some of the groups did not follow a normal distribution, non-parametric methods were used for the statistical evaluation of the data. Results are expressed as median and range. The Kruskal-Wallis one way analysis of variance by ranks $(\mathrm{H})$ and the Mann-Whitney $U$ test respectively were used to examine for any significant differences and subsequently to make pair wise comparisons between groups. Within groups the Quade's two way analysis of variance by ranks for repeated measures $(T)^{24}$ was used to examine for any dose-response effect of the peptides. Kendall's $\tau$ correlation was used to examine for the relationship between the values of either the migration or the stimulation index in the subgroup of the treated coeliac patients $(n=12)$ tested by migration and proliferation assays using both synthetic peptides. 


\section{Results}

INDIRECT LEUCOCYTE MIGRATION

INHIBITION ASSAYS

Using $33.3 \mu \mathrm{g} / \mathrm{ml}$ and $11 \cdot 1 \mu \mathrm{g} / \mathrm{ml}$ viral peptide the median (range) migration indices respectively were $0.79(0.51-1.13)$ and $0.90(0.65-1.52)$ for treated coeliac patients, $1.07(0.81-1.56)$ and $1 \cdot 10(0 \cdot 83-1 \cdot 70)$ for healthy subjects $(\mathrm{p}<0.001)$, $1 \cdot 0(0.84-1 \cdot 22)$ and $1 \cdot 10(0.85-1 \cdot 42)$ for patients with ulcerative colitis $(\mathrm{p} \leq 0.002)$, and $1.0(0 \cdot 81$ $1.70)$ and $1.0(0.95-1.50)$ for patients with Crohn's disease $(\mathrm{p}<0.001)$. For the lowest concentration $(5.55 \mu \mathrm{g} / \mathrm{ml})$ there were no significant differences between the groups $(\mathbf{H}=5.65$, $p=0 \cdot 13$ ). No significant difference was found between healthy subjects and either group of disease control subjects at all concentrations of the viral peptide $(p>0.05)$. Figure 1 shows the scatter of the values of the migration indices at $33.3 \mu \mathrm{g} / \mathrm{ml}$ viral peptide antigen. There was a dose-response effect when the viral peptide was tested at three different concentrations in the treated group of coeliac patients (Fig 2).

The migration indices from untreated coeliac patients lay within the range of those obtained from control groups $(p>0.05)$ and were higher than for the vast majority of treated coeliac patients (Fig 3). When five coeliac patients were studied serially in response to a gluten free diet the migration indices fell remarkably (Fig 3).

To examine the correlation between the migration indices obtained with the gliadin and the viral peptides simultaneous assays using both peptides were performed in 12 patients from the treated group of coeliac patients and 12 matched subjects from the healthy control group. The migration indices from the group of coeliac patients $(0.77(0.63-0.96))$ were significantly lower than for the control group (1.05 (0.92$1 \cdot 40)$, Mann-Whitney U test $=1 \cdot 5, \mathrm{p}<0.001)$ at $33.3 \mu \mathrm{g} / \mathrm{ml}$ gliadin peptide. The results for the viral peptide were similar $(0.80(0.60-1.00)$ compared with $1 \cdot 13(0.81-1 \cdot 56)$, MannWhitney $U$ test $=8 \cdot 0, p<0 \cdot 001)$. The correlation between the migration indices for the gliadin and viral peptide was highly significant (Kendall's $\tau$ correlation, $\tau=0 \cdot 719, n=12, p<0 \cdot 001$ ) (Fig 4).

\section{PROLIFERATION ASSAYS}

Stimulation indices from treated coeliac patients were significantly higher than for healthy controls at all concentrations of both peptides in the six day cell cultures (Table). Figure 5 shows the scatter of stimulation indices for viral and gliadin

Figure 1: Migration indices in patients with treated coeliac disease (TCD), healthy controls (HC), and patients with ulcerative colitis (UC) and Crohn's disease (Crohn's) at 33.3 $\mu g / m l$ viral peptide. Horizontal lines represent median. The dotted line indicates the lowest migration index value in the control groups. KruskalWallis one way analysis of Wallis one way analysi
variance $(H=23 \cdot 560$, $p<0.001)$. ${ }^{\star}$ Value in TCD group significantly different from control groups (MannWhitney U test, $p<0.001$ ). peptides (concentration $33.3 \mu \mathrm{g} / \mathrm{ml}$ ). There was

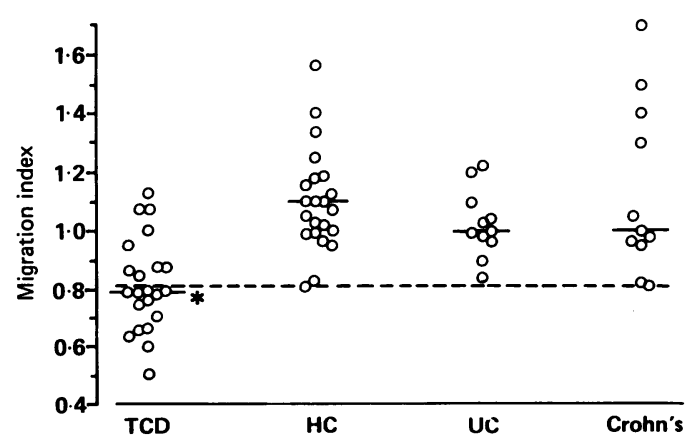

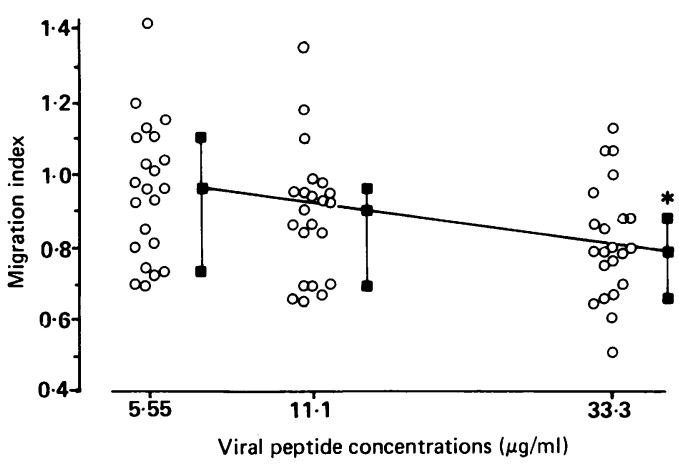

Figure 2: Effect of three different concentrations of the viral peptide on cells from treated coeliac patients $(n=22)$. Open circles indicate values of migration indices. Vertical lines represent median and interquartile range. Quade's two way analysis of variance $(T=3.68, p<0.05)$. ${ }^{\star}$ Values at $33.3 \mu \mathrm{g} /$ $\mathrm{ml}$ significantly different from $11 \cdot 1 \mathrm{\mu g} / \mathrm{ml}$ and $5.55 \mu \mathrm{g} / \mathrm{ml}$ $(p<0.05)$.

a dose-response effect for both peptides when tested at three different concentrations in the subgroup of treated coeliac patients (Figs 6 and $7)$. In the same subgroup a significant correlation was found between the stimulation indices obtained using the viral and the gliadin peptides at $33.3 \mu \mathrm{g} / \mathrm{ml}(\tau=0.708, \mathrm{n}=12, \mathrm{p}<0.001)$ (Fig $8), 11 \cdot 1 \mu \mathrm{g} / \mathrm{ml}(\tau=0.848, \mathrm{n}=12, \mathrm{p}<0.001)$, and $5.55 \mu \mathrm{g} / \mathrm{ml}(\tau=0.576, \mathrm{n}=12, \mathrm{p}<0.01)$. In addition, a significant negative correlation was found in the same subgroup between the stimulation and the migration index at the highest concentration of both the viral $(\tau=-0.481, n=12$, $\mathrm{p}<0.02)$ and the gliadin peptides $(\tau=-0.605$, $\mathrm{n}=12, \mathrm{p}<0.005$ ).

\section{HLA TYPING}

Twenty two of the coeliac patients had the serological haplotype HLA B8,DR3,DQ2. The remaining three had $B 27, D R 7, D Q 2$; $\mathrm{B} 7, \mathrm{DR} 2, \mathrm{DQ} 1$; and $\mathrm{B} 7, \mathrm{DR} 3, \mathrm{DQ} 2$ respectively. Among healthy subjects two had B8,DR3,DQ2 and two had DR4,DQ1; another three had B18,DR3,DQ2; B7,DR7,DQ2; and B51,DR7,DQ2 respectively.

\section{Discussion}

In this study we tested a synthetic dodecapeptide sequence from the Elb protein of Ad12 (residues 384-395), which is closely homologous to a

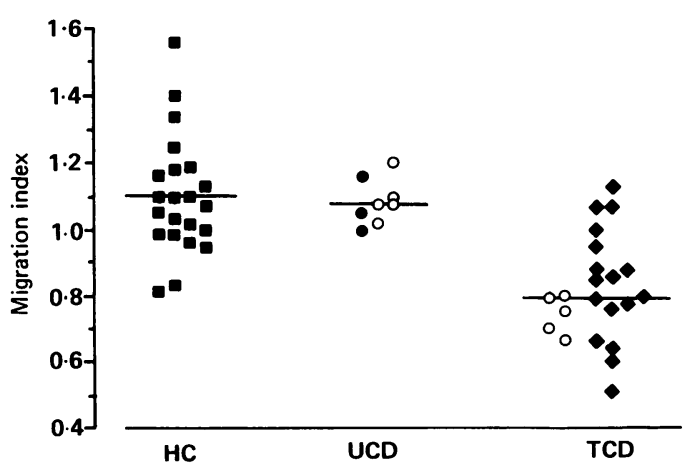

Figure 3: Migration indices in healthy controls $(H C)(n=22)$ and in patients with untreated coeliac disease (UCD) $(n=8)$ and treated coeliac disease $(T C D)(n=22)$ at $33 \cdot 3 \mu \mathrm{g} / \mathrm{ml}$ viral peptide. Open circles represent coeliac patients serially tested in response to gluten free diet. Horizontal lines represent median. 
Figure 4: Scatter of the migration indices (MI) a $33 \cdot 3 \mathrm{\mu g} / \mathrm{ml}$ viral and $33 \cdot 3$ $\mu \mathrm{g} / \mathrm{ml}$ gliadin peptide in treated coeliac patients $(n=$ 12). Kendall's $\tau$ correlation $(\tau=0 \cdot 719, p<0.01)$

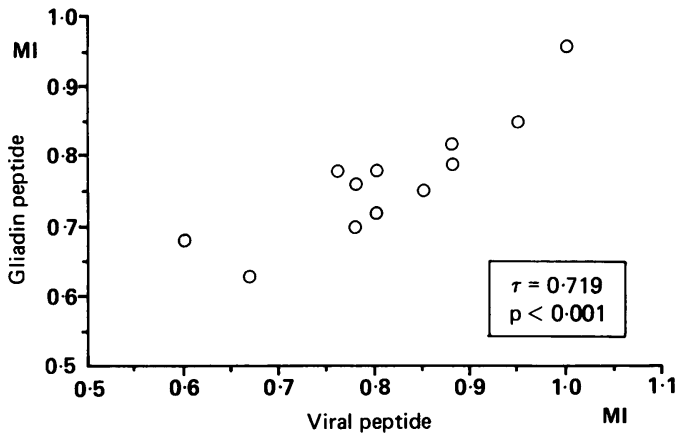

sequence contained in A-gliadin, for its effect on peripheral blood mononuclear cells from coeliac patients and controls using immunological assays which detect different stages of the lymphocyte response to antigens. The premise was that if this viral sequence was recognised by $T$ cells, lymphocytes from sensitised subjects would proliferate in response to the synthetic viral peptide and also release leucocyte migration inhibition factor (LMIF). The presence of this lymphokine could subsequently be assayed for its effect on the inhibition of migration under agarose of polymorphonuclear cells from healthy donors.

In the migration inhibition assays peripheral blood mononuclear cells of treated coeliac patients as a whole showed a significantly different response to the viral peptide from that seen in healthy subjects or patients with inflammatory bowel disease. Although there were treated coeliac patients showing no sensitisation and, conversely, a few control subjects with a migration index overlapping those in the treated coeliac group, nearly all of the migration index values in the latter group were clearly below the lowest value in the control groups. This value is considered to indicate the upper limit of sensitisation to the peptide since the data were not distributed normally. The extent of this overlap was slightly less for the gliadin peptide than for the viral peptide in the subgroup of 12 treated coeliac patients and healthy control subjects. However, in the subgroup of treated coeliac patients there was a significant correlation between the migration indices so that responders to the gliadin peptide tended to be responders to the viral peptide as well. This overlap in migration indices may reflect the occurrence of adenovirus 12 infection in the community rather than major differences in the specificity and sensitivity of the two synthetic peptides in coeliac

Median (range) of the stimulation indices for viral peptide and gliadin peptide in a subgroup of treated coeliac patients and healthy controls

\begin{tabular}{|c|c|c|c|c|}
\hline & \multirow{2}{*}{$\begin{array}{l}\text { No } \\
\text { tested }\end{array}$} & \multicolumn{3}{|c|}{ Concentrations of peptides $(\mu g / m l)$} \\
\hline & & $33 \cdot 3$ & $11 \cdot 1$ & $5 \cdot 55$ \\
\hline $\begin{array}{l}\text { Viral peptide: } \\
\text { Treated coeliac patients } \\
\text { Healthy control subjects }\end{array}$ & $\begin{array}{l}12 \\
12\end{array}$ & $\begin{array}{l}1.78(1.01-4.50)^{\star} \\
0.90(0.60-1.37)\end{array}$ & $\begin{array}{l}1.64(0.58-3.81)^{\star} \\
0.89(0.48-1.23)\end{array}$ & $\begin{array}{l}1 \cdot 35(0.67-2 \cdot 39)^{\star} \\
0.89(0.41-1 \cdot 11)\end{array}$ \\
\hline $\begin{array}{l}\text { Gliadin peptide: } \\
\text { Treated coeliac patients } \\
\text { Healthy control subjects }\end{array}$ & $\begin{array}{l}12 \\
12\end{array}$ & $\begin{array}{l}2.40(1.20-6 \cdot 00) \dagger \\
0.90(0.58-1.13)\end{array}$ & $\begin{array}{l}1.50(0.76-3.16) \dagger \\
0.94(0.52-1.13)\end{array}$ & $\begin{array}{l}1.60(0.83-2 \cdot 48) \dagger \\
0.89(0.68-1 \cdot 10)\end{array}$ \\
\hline
\end{tabular}

$\star$ Values in treated patients significantly different from those in control group at the same concentration of the viral peptide (Mann-Whitney U test: ${ }^{\star} p<0 \cdot 001$ )

†Values in treated patients significantly different from those in control group at the same concentration of the gliadin peptide (Mann-Whitney $U$ test: $t p<0.001$ ).

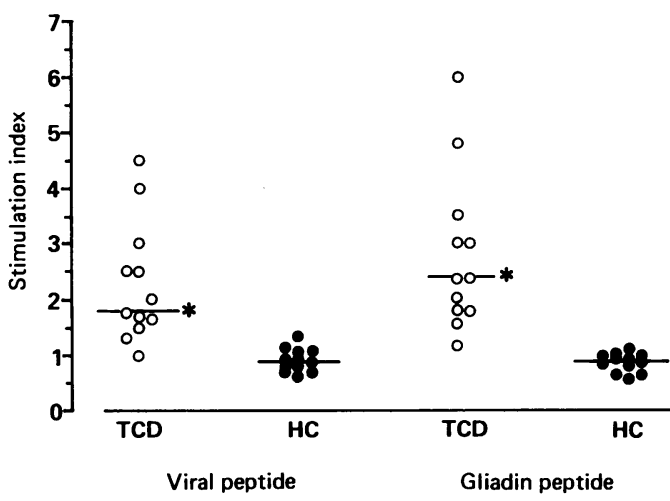

Figure 5: Stimulation indices in treated patients with coeliac disease $(T C D)(n=12)$ and healthy controls $(H C)(n=12)$ at $33.3 \mu \mathrm{g} / \mathrm{ml}$ viral (left) and $33.3 \mu \mathrm{g} / \mathrm{ml}$ gliadin peptide (right). Horizontal lines represent median. ${ }^{\star}$ Value in TCD group significantly different from $\mathrm{HC}$ group (Mann-Whitney $U$ test, $p<0.001$ )

disease. Indeed, although detailed epidemiological data for Ad12 are lacking, such double stranded DNA viruses can be detected in the gastrointestinal tract of infants and children early in childhood. ${ }^{25}$ Accordingly, Kagnoff et $a l^{14}$ detected neutralising antibody to Ad12 in the sera of up to $12 \cdot 8 \%$ of healthy and disease control subjects. It is notable that high values were seen in a few healthy subjects and patients with Crohn's disease and may thus account for the wide range of the migration index in these groups.

The pattern of the responses in untreated coeliac patients tested serially before and after the introduction of a gluten free diet is strikingly similar to that seen in a previous study using the synthetic gliadin peptide ${ }^{20}$ and is in keeping with studies using various gluten derived peptides. ${ }^{27} 28$ This response may be brought about by viral peptide sensitive $T$ lymphocytes, which leave the intestinal mucosa and recirculate in the peripheral blood after the intestinal inflammation has settled on a gluten free diet, in the same way that has been suggested for gluten sensitive lymphocytes. ${ }^{29}$

Skin testing to detect delayed type hypersensitivity to the viral peptide was not performed. It has been shown, however, that lymphocytes from treated coeliac patients stimulated with the gliadin synthetic peptide release a lymphokine

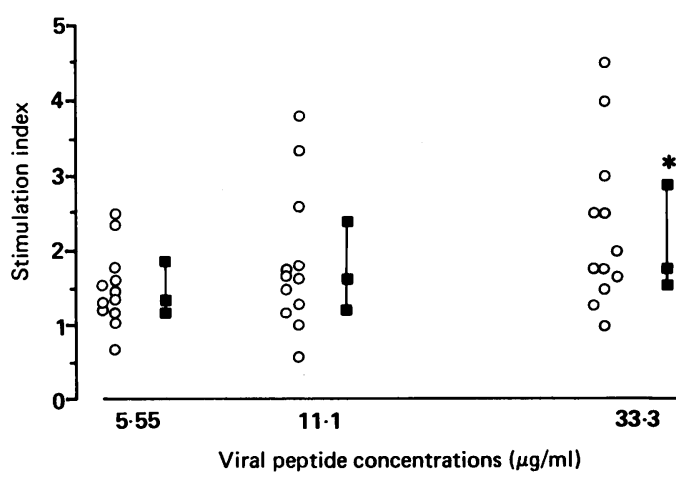

Figure 6: Dose-response effect of three different concentrations of viral peptide in patients with treated coeliac disease $(n=12)$. Open circles indicate stimulation indice values. Vertical bars represent median and interquartile range. Quade's two way analysis of variance $(T=7.99, p<0.05) .{ }^{\star}$ Values at $33.3 \mu \mathrm{g} /$ $\mathrm{ml} \mathrm{significantly} \mathrm{different} \mathrm{from} 11 \cdot 1 \mathrm{\mu g} / \mathrm{ml}$ and $5.55 \mu \mathrm{g} / \mathrm{ml}$ $(p<0.01)$. 
Figure 7: Dose-response effect of three different concentrations of gliadin peptide in patients with treated coeliac disease $(n=$ 12). Open circles indicate values of stimulation indices. Vertical bars represent median and interquartile range. Quade's two way analysis of variance $(T=$ $11 \cdot 07, p<0 \cdot 01)$. ${ }^{\star}$ Values at $33.3 \mu \mathrm{g} / \mathrm{ml}$ significantly different from $11 \cdot 1 \mu \mathrm{g} / \mathrm{ml}$ and $5.55 \mu \mathrm{g} / \mathrm{ml}(p<0.01)$.

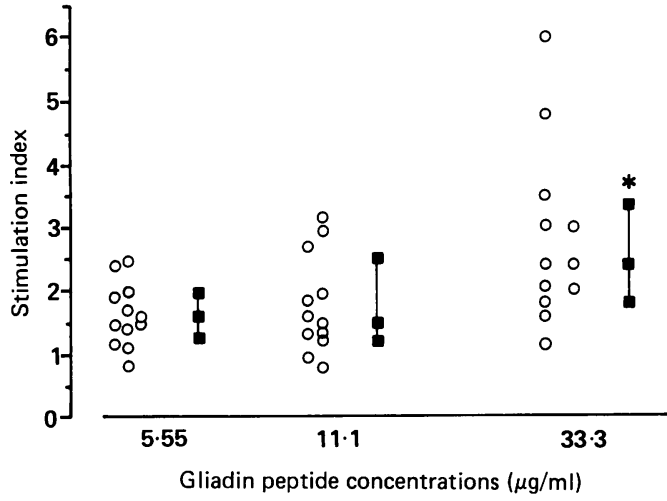

with many of the properties of LMIF. ${ }^{30}$ Given the similarities, those already mentioned and those that follow, between the immunological behaviour of the two synthetic peptides, it would be surprising if a different mechanism was involved. In addition, we have shown (unpublished observations) that in assays performed simultaneously the migration indices from peripheral blood unfractionated mononuclear cells in treated coeliac patients were not significantly different from those obtained using a pure $T$ cell population with the addition of adherent cells. Therefore, we believe that LMIF from sensitised lymphocytes was released in the assay and that the low migration index is indeed an expression of cell mediated immunity to the viral peptide.

It has been hypothesised that peripheral blood mononuclear cells of HLA-B8 control subjects are more sensitive to gluten fractions than those from a non-HLA-B8 donor. ${ }^{31}$ This has not been confirmed in other studies. ${ }^{2029}$ In our study no such correlation was found in any group, using either the gliadin or the viral synthetic peptide. B8,DR3,DQ2 coeliac patients were both responders and non-responders to the viral peptide. The patient who had B7,DR2,DQ1 showed a low migration index. Conversely, only one of the two control subjects with B8,DR3,DQ2 and DR4, DQ1 respectively had a low migration index.

In the proliferation assays the overall responses of peripheral blood lymphocytes from treated coeliac patients to both synthetic peptides were not impressive. This does not reflect an inherent lack of ability of these cells to respond to other stimuli. Indeed, the stimulation indices from phytohaemagglutinin stimulated lymphocytes of treated coeliac patients were comparable to those of control subjects and significantly higher than those obtained using

Figure 8: Scatter of stimulation indices $(S I)$ a $33 \cdot 3 \mu \mathrm{g} / \mathrm{ml}$ viral peptide and $33.3 \mu \mathrm{g} / \mathrm{ml}$ gliadin peptide in treated coeliac patients $(n=12)$. Kendall's correlation $(\tau=0 \cdot 708$ $p<0.001)$. either the viral or the gliadin peptide (data not shown). This finding is consistent with results of earlier studies using various gluten fractions..$^{21}{ }^{32} 33$ In spite of the relatively weak response to both peptides, interesting and complementary similarities were seen between the proliferation and the migration assays in this subgroup of the study. Firstly, the proliferative response of peripheral blood mononuclear cells from treated coeliac patients was significantly higher than that for healthy subjects for all the concentrations of the gliadin peptide and the viral peptide. Secondly, no control subject responded to the gliadin peptide. Thirdly, one of the healthy subjects showed a weak response to the viral peptide. Interestingly, he was the same control who had a low migration index in the migration assay. Consequently, there was some overlap in stimulation indices for the viral peptide but only minimal overlap for the gliadin peptide between the treated coeliac patients and the healthy control subgroups, as seen in the migration assay. Finally, most of the treated coeliac patients were more responsive to the gliadin peptide than to the viral peptide. The stimulation indices for the gliadin peptide and the viral peptide showed a highly significant correlation in the treated coeliac patients, similar to that seen between the migration indices.

To our knowledge, no dietary protein such as $\alpha$ lactalbumin, ${ }^{33}{ }^{35}$ bovine $\beta$ lactoglobulin, ${ }^{33}$ casein, ${ }^{28335}$ chicken ovalbumin, ${ }^{35}$ or maize zein fraction $\mathrm{B},{ }^{35}$ when tested in these assays, has produced a significantly different effect on the peripheral blood mononuclear cells of treated coeliac patients than on those in controls.

The results of this study show that a synthetic dodecapeptide from Ad12, which is closely homologous to a sequence contained in Agliadin, elicits a strong response from the peripheral blood lymphocytes of many treated coeliac patients, but not from the vast majority of healthy subjects or patients with inflammatory bowel disease. These responses were less impressive than those elicited by the synthetic peptide from the corresponding A-gliadin epitope both in this and a previous study..$^{20}$ However, these responses obtained in assays performed simultaneously not only followed an identical pattern in untreated and treated coeliac patients, but were highly correlated.

The possibility that a human intestinal adenovirus might initiate an immune response to gluten triggering a cascade of immunological events that lead to coeliac disease is not only intriguing, but may provide the necessary environmental factor to explain some of the controversies in this disease, such as the discordance in monozygotic twins. ${ }^{81112}$ Our results support this hypothesis but do not prove it.

This study was generously supported by the Coeliac Trust. The gliadin and viral peptides were kindly provided by Dr Ronny gliad in Alan Ting and Mr Craig Taylor, Nuffield Depertment of Surg Dr

1 Woychik JH, Boundy JA, Dimler RJ. Starch gel electrophoresis of wheat gluten proteins with concentrated urea. Arch Biochem Biophys 1961; 94: 477-82.

2 Kumar PJ, Sinclair TS, Farthing MJG, et al. Clinical toxicity testing of pure gliadins in celiac disease [Abstract]. Gastroenterology 1984; 86: 1147 . 
3 Kasarda DD. Structure and properties of a-gliadins. Ann Tech Agric 1980; 29: 151-3.

4 Kasarda DD. Toxic proteins and peptides in celiac disease: relations to cereal genetics. In: Walcher D, Kretchmer M, eds. Food, nutrition and evolution. New York: Masson, 1981: 201-16.

5 Kasarda DD, Okita TW, Bernardin JE, et al. Nucleic acid (cDNA) and amino acid sequences of a-type gliadins from wheat (Triticum aestivum L). Proc Natl Acad SciUSA 1984; 81: $4712-6$.

6 Stokes PL, Asquith P, Holmes GKT, MacKintosh P, Cooke WT. Histocompatibility antigens associated with coeliac WT. Histocompatibility antige

7 Albert EJ, Harms K, Wank R, Steinbauer-Rosenthal I, Schultz S. Segregation analysis of HL-A antigens and haplotypes in 50 families of patients with celiac disease. Transplant Proc 1973; 5: 1785-9.

8 Mearin ML, Biemond I, Pena AS, Polanco I, Vasquez C. HLA-DR phenotypes in Spanish coeliac children: their contribution to the understanding of the genetics of the disease. Gut 1983; 24: 532-7.

9 Howell MD, Austin RK, Kelleher D, Nepom GT, Kagnoff MF. An HLA-D region restriction fragment length polymorphism associated with celiac disease. $\mathcal{F}$ Exp Med 1986; 164: 333-8.

10 Niven MJ, Gaffrey C, Sachs JA, et al. Susceptibility to coeliac disease involves genes in the HLA-DP subregion. Lancet disease involves

11 Shale DJ, Johnston DG, Hall R, Robert DF. Coeliac disease in monozygotic twins. Postgrad Med f 1982; 58: 797-8.

12 Polanco I, Biemond I, Van Leeuwen A, et al. Gluten-sensitive enteropathy in Spain: genetic and environmental factors. In: McConnell RB, ed. The genetics of coeliac disease. Lancaster: MTP Press, 1981: 211-31.

13 Polanco I, Mearin ML, Larrauri J, Biemond I, Wipink-Baker A, Pena AS. Effect of gluten supplementation in healthy siblings of children with celiac disease. Gastroenterology 1987; 92: 678-81.

14 Kagnoff MF, Austin RK, Hubert JJ, Kasarda DD. Possible role for a human adenovirus in the pathogenesis of celiac role for a human adenovirus in the patho

15 Kyte J, Doolittle RF. A simple method for displaying the hydropathic character of a protein. $7 \mathrm{Mol} \mathrm{Biol} \mathrm{1982;157:}$ hydropa $105-32$.

16 Kagnoff MF, Austin RK, Johnson HCL, Bernardin JE, Dietler MD, Kasarda DD. Celiac sprue: correlation with murine T-cell responses to wheat gliadin components. f Immunol 1982; 129: 2693-7.

17 De Ritis G, Auricchio S, Jones HW, Lew EJ-L, Bernardin JE, Kasarda DD. In vitro (organ culture) studies of the toxicity of specific A-gliadin peptides in celiac disease. Gastroenterology 1988; 94: 41-9.

18 Kagnoff MF, Paterson YJ, Kumar PJ, et al. Evidence for the role of a human intestinal adenovirus in the pathogenesis of coeliac disease. Gut 1987; 28: 995-1001.
19 Howdle PD, Blair Zajdel ME, Smart CJ, Trejdosiewicz LK, Blair GE, Losowsky MS. Evidence against the involvement of adenovirus 12 in the pathogenesis of coeliac disease [Abstract]. Gut 1988; 29: A1469.

20 Karagiannis JA, Priddle JD, Jewell DP. Cell-mediated immunity to a synthetic gliadin peptide resembling a sequence from adenovirus 12 . Lancet 1987; i: 884-6.

21 Karagiannis JA, Jewell DP. Cellular hypersensitivity in celiac disease. Immune responses of sensitized lymphocytes to a synthetic dodecapeptide sequence from A-gliadin a synthetic dodecapeptide sequence from

22 Terasaki PI, Bernoco D, Parks MS, et al. Microdroplet testing for HLA-A,B,C and DR antigens. Am $\mathcal{F}$ Pathol 1978; 69: 103-20.

23 Clausen JE. Migration inhibitory effect of cell-free supernatants from tuberculin-stimulated cultures of human mononuclear leucocytes demonstrated by two-step MIF agarose assay. $\mathcal{F}$ Immunol 1973; 110: 546-51.

24 Conover WJ. In: Practical non-parametric statistics. 2nd ed. New York: John Wiley, 1980: 295-9.

25 Flint SI. Structure and genomic organization of adenoviruses. In: Tooze J, ed. DNA tumor viruses. New York: Cold Spring Harbor Laboratories, 1980: 383-441.

26 Middleton PJ. Role of viruses in pediatric gastrointestinal disease and epidemiologic factors. In: Tyrrell DAJ, disease and epidemiologic factors. In: Tyrrell DAJ, Kew York: Dekker, 1982: 211-25.

27 Bullen AW, Losowsky MS. Cell-mediated immunity to gluten fraction III in adult coeliac disease. Gut 1978; 19: 126-31.

28 O'Farrelly C, Feighery CF, Greally JF, Weir DG. Cellular response to alpha-gliadin in untreated coeliac disease. Gut 1984; 23: 83-7.

29 Howdle PD, Bullen AW, Losowsky MS. Cell-mediated immunity to gluten within the small intestinal mucosa in coeliac disease. Gut 1982; 23: 115-22.

30 Lydford-Davis H, Karagiannis JA, Priddle JD, Jewell DP. Preliminary characterization of leucocyte migration inhibition factor (LIF) produced by lymphocytes from coeliac patients when stimulated with gluten peptides. Clin $\mathrm{Sci}$ patients when

31 Simpson FG, Bullen AW, Robertson DAF, Losowsky MS. HLA-B8 and cell-mediated immunity to gluten. Gut 1981; 22: 633-6.

32 Holmes GKT, Asquith P, Cooke WT. Cell-mediated immunity to gluten fraction III in adult coeliac disease. Clin Exp Immunol 1976; 24: 259-65.

33 Sikora K, Anand BS, Truelove SC, Ciclitira PJ, Offord RE. Stimulation of lymphocytes from patients with coeliac disease by a subfraction of gluten. Lancet 1976; ii: 389-91.

34 O'Farrelly C, Whelan CA, Feighery CF, Weir DG. Suppressor-cell activity in coeliac disease induced by alphagliadin, a dietary antigen. Lancet 1984; ii: 1305-7.

35 Guan R, Rawcliffe PM, Priddle JD, Jewell DP. Cellular hypersensitivity to gluten derived peptides in coeliac disease. Gut 1987; 28: 426-34. 